

\section{Shirkah}

\section{Journal of Economics and Business \\ Vol. 1, No. 1, January-April 2016 \\ ISSN: 2503-4235 (p); 2503-4243 (e)}

\section{Editor in Chief}

Sri Walyoto

\section{Editorial Boards}

Ahmad Ihwan Setiawan, Faculty of Economics, Universitas Sebelas Maret

Dwi Condro Triono, Faculty of Islamic Economics and Business, IAIN

Surakarta

Fahmy Radhi, Faculty of Economics, Universitas Gadjah Mada

Jaka Sriyana, Faculty of Economics, Universitas Islam Indonesia

\section{Managing Editors}

M. Endy Saputro

M. Zainal Anwar

\section{Assistant to Editor}

Supriyanto

Shirkah Journal of Economics and Business is a peer-reviewed journal published three times a year (January-April, May-August and September-December) by Faculty of Islamic Economics and Business, Institut Agama Islam Negeri (IAIN/ State Institute for Islamic Studies) Surakarta Central Java, Indonesia. The main objective of Shirkah is to offer an academic space of exchange ideas and initiate the increase number of qualified article produced by postgraduate students, practitioners and academicians.

\section{Editorial Office}

Ruang Jurnal Shirkah

Lantai Dasar, Sayap Barat, Fakultas Ekonomi dan Bisnis Islam, IAIN Surakarta

Jln. Pandawa No. 1, Kartasura, Sukoharjo, Jawa Tengah Kode Pos. 57168

Phone (+62271) 781516 Fax: (+62271)782336

E-mail: shirkahiainsurakarta@gmail.com

Website: http://shirkah.or.id/ 


\section{Shirkah}

Journal of Economics and Business

Vol. 1, No. 1, January-April 2016

ISSN: 2503-4235 (p); 2503-4243 (e)

\section{Table of Contents}

\section{Articles}

Muthmainah

The Growth of Sharia Insurance in Indonesia 2015 - 2016

An Academic Forecast Analysis

Meilana Widyaningsih

$23-46$

The Effect of Material, Social and Activities Compensations

toward Work Performance Using Organizational Commitment

as The Mediator

Tri Wabyuni

$47-72$

The Influence of Technology Acceptance Model (TAM)

on The Users' Behavior of Sikesya Application in IAIN Surakarta

M. Nidaussalam

Mudaraba as a Model of Islamic Finance

Sri Maryati

$93-112$

Evaluating The Performance of Inventory Management

The Production Division of PT. Tiga Serangkai Surakarta

as a Case Study

Mardhiyaturrositaningsih

$113-126$

Sharia Banking's Profit Loss Finance in the Context of ASEAN Economic Community 


\title{
Mudaraba as a Model of Islamic Finance
}

\author{
M. Nidaussalam \\ Islamic Law, Graduate Program, \\ State Islamic University (UIN) Yogyakarta
}

\begin{abstract}
Sharia bank has mostly been determined by its absent of rate transaction which is officially decided in agreement between the bank and its customer (akad). Mudharaba, one of the akad variants, offers equity finance requiring profit and loss sharing (PLS). This paper aims to critically discuss the principles of mudharaba commitment, mainly focusing on the process of funding and financing. To argue, mudharaba is an cooperating commitment between two economic agencies for which the first agency expected to provide financial capital while the other takes a part in managerial work-progress. In this process, the more profit for mudharib the more profit for the investor.
\end{abstract}

\section{Keywords}

Mudharaba, islamic finance, profit and loss sharing

Bank is an institution to implement three main functions, namely accepting money saving, lending money, and money transferring. The economic history shows bank's function has been known since the prophet Muhammad (PBUH) era. The functions are accepting entrusted treasure, lending money for consumption and business needs, and sending money (Biro Perbankan Syariah Bank Indonesia, 2001). Bank is business entities that collects funds from society in saving form and then distribute them in credits and/ or other form to enhance society's standard of living. Conventional banking has not yet achieved these financing activities 
therefore the establishment of sharia banking.

The main businesses in banking are society's fund management and its contribution to the society; finance services; and other finance activities. Sharia banking is a pure intermediation institution with all customer deposits fund allocate in financing. Therefore it has higher level of credit risk's exposure. Sharia bank should be more selective in financing their customers due to the long tenor which will affect assets management and banking liability. The fact shows bank as a finance intermediation institution are funding from its customers saving in a relatively short period. The customer inability to pay the funding as mentioned in the contract will affect the sharia banking finance.

Sharia bank asset balance will show most assets are allocated at financing department. It is equitable due to banking main function as intermediation institution and its main business. According to Law no. 21, 2008, sharia bank has been defined as everything relate to sharia bank and sharia business units, its institution, activities, and also process and procedure in implementing its activities. In doing so, the main incomes of the bank is funding and financing. However, there are big risks on financing. There are various risks on financing such as operational and credit risk. Customers who fail to pay (default) will significantly affect sharia bank assets and liquidity.

Sharia bank does not use interest in its operation. Therefore it uses contract mechanism to connect with the customers (creditors and debtors). It outlines with equity finance, trade finance and rent finance. Mudharaba contract is one of sharia bank contract of equity finance variant. It has profit and loss sharing (PLS) concept. This paper critically explains the mudharaba transaction contract, especially on mudharaba funding and financing relates to the sharia banking investment in Indonesia. 


\section{Defining Mudbaraba}

Mudharaba derived from the word dharb meaning hitting, more aptly defining as a personal process in hitting his feet to operate his/ her business. It also means walk on the earth which usually named traveling. Mudharaba or qiradh is included in shirkah category. Mudharaba is used in Iraqi's language; therefore the Hijaz named it qiradh. The Qur'an does not mentioned mudharaba clearly in the form of mudharabah word. The Qur'an mentioned it in the word dharaba for 58 times (Huda, 2010).

According to Brian Kettel (2008), mudharaba is derivative language of Arabic word darb fi al-ard which means walking on earth (yadribuna fi al-ard). It comes from Qur'anic letter al-Muzammil verse 20 on an establishment of profit partnership of capital and work between account holder investments as modal owner and sharia bank as mudharib (managing partner). Furthermore, PSAK no. 105 defines Mudharabah as working contract of two parties, namely first party (fund owner) who provides all funds, and second party (fund manager) as manager. The business profit is divided among according to agreement, with financial loss is only borne by the fund manager.

Mudharaba, according to Syafii Antonio (2001), technically means a working contract of two parties, whereby the first party (shahibul maal) provides all modal which other party managed. Based on mudharaba system, the profit should be divided according to the initial agreement. The loss will be borne by the modal owner as long as it does not due to modal manager's negligence. Whether the loss is caused by the modal manager negligence or fraud the loss will be the borne by the modal manager. Mudharaba is a partnership contract based on profit and loss sharing principle. It is signed by at least two parties, the first party is modal owner and provider, named shahibul maal and the second party is the party with skill and responsibility on fund management/ certain halal business, 
named mudhorib (Ilmi, 2002).

Fiqh scholars agree on the statement of mudharaba is a requirement in Islam based on the Qur'an, sunnah, ijma', and qiyas (Rachmat, 2001). According to sharia basis, mudharaba explains the need to do business which shows on these the Qur'an verses and hadith:

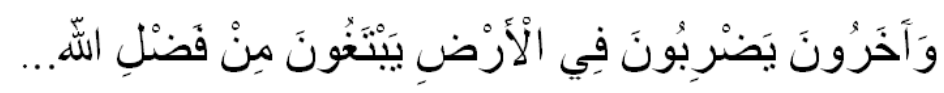

Meaning: “... and some of them walking on earth looking for God's bounty...."

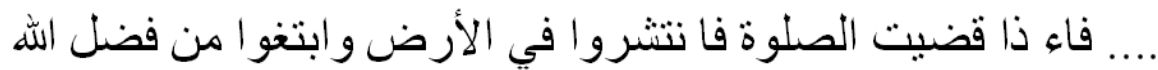

Meaning: "And when the prayer is finished, then may you disperse through the land and seek the bounty of the God ..." (al-Jumu'a, 10)

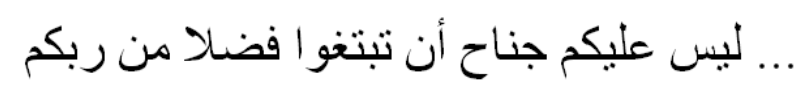

Meaning: "It is no crime in you if you seek of the bounty of your Lord ..." (al-Baqara, 198)

عن صالح بن صهيب عن أبيه قال قال رسول الله صلى الله عليه و سلم ثلاث فيهن البركة ؛ \} البيع إلى أجل و المقارضة و أخلاط البر بالثعبر للبيت لا للبيع

From Shalih bin Shuhaib, Rasullulah (PBUH) said, "There are three things full of blessing: strong trading, muqaradhah (mudharabah), and mixing wheat and flour for household needs not for trading." (Ibnu Majah, No. 2280, book at-Tijarah)

Hadith of Abdullah and 'Ubaidullah, two sons of Umar, met Musa al-Asy'ary in Basrah, after going home from Nawahand. Both are accepting treasure from Abu Musa to be brought to Madinah (the capital). On the way they bought jewelry, then sold them in Madina therefore they made 
some profit. Umar decided to to take all the modal and profit. However his two sons said, "If these treasures are gone, aren't we the one who replaced them, how couldn't we gain some profit from them? "Someone said to Umar, "Amirul Mukminin the treasures establish as qiradh." Umar accepted this idea, he said, "I will make them into qiradh." Umar took half of the profit (50\% for baitul maal 50\% for both of his sons).

The prophet companions has concessed on orphan treasure management as mudharaba. The ijma' in mudharaba said there is a report concerning Prophet's word there are prophet companions who used orphan treasure as mudharaba. This action was not conflicted by other companions. Mudharabah in qiyas is categorized as al-musyaqa (somebody who manage the garden). People are consist of the poor and the rich. There are rich people who could not cultivate his treasure. However there are poor people who want to establish business but do not have modal. The mudharaba's purpose is to connect these two parties, and establish human prosperity in fulfilling their need.

Dewan Syariah Nasional (National Sharia Council/DSN) issued fatwas on mudharabah transaction:

a. DSN fatwa No. 07/DSN-MUI/IV/2000 on Mudharaba (Qiradh)

b. DSN MUI fatwa No. 33/DSN-MUI/IX/2002 on Sharia Mudharaba Obligation

c. DSN fatwa 38/DSN-MUI/X/2002 on Interbank Mudharaba Investment Certificate

d. DSN fatwa 50/DSN-MUI/III/2006 on Mudharaba Mushtaraka Contract

e. DSN fatwa No: 51/DSN-MUI/III/2006 on Mudharaba Mushtaraka of sharia insurance

According to DSN fatwa No: 07/DSN-MUI/ IV/2000 on Mudharaba (qiradh) funding is divided into three parts, namely mudharaba 
financing provision:

a) Mudharabah financing provision:

- Mudharabah financing is a financing distributed by LKS for all productive businesses.

- Of all these financings LKS position is shahibul maal (capital owner) with $100 \%$ financing of project (business) needs, therefore the business person (customer) is mudharib (business manager).

- Business time period, refund procedure, and profit sharing are measured by the agreement of both parties (LKS and business person).

- Mudharib is allowed to do various businesses agreed upon and in accordance with sharia. LKS does not involve in business management or other project, however it has right to train and observe.

- The total amount and financing has to be transparent and in cash and not in credit.

- LKS as fund provider will bear all loss of the mudaharaba unless the mudharib made a deliberate error, negligent, and violate the agreement.

- The principle is there is no guarantee in mudharaba financing. However, to prevent mudharib make a mistake LKS is allowed to quires guarantee from the mudharib or third party. The guarantee is only able to liquidate whether mudharib violates the agreements on the contract.

- Business person criteria, procedure, and profit sharing mechanism are arranged by LKS in accordance with DSN fatwa.

- Operational fee is charged on the mudharib.

- Mudharib may regain compensation or the incurred cost whether LKS does not carry out its duty or violates the agreement 
b) Mudharaba Financing Conditions and Rules This point will simplify the provision in the DSN MUI fatwa based on Muhammad's (2008) paper. It mentions mudharaba contract will operate whether it follows the rules:

- Shahibul maal (capital owner)

- Mudharib (operator/ business person)

- Modal (maal)

- Work/ business

- Profit

- Consent and qabul

The conditions of mudharaba contract are:

i. $\quad$ Funding provider and manager should be legal aware.

ii. Consent and qabul statement should be said by the related parties to show their volition, with awareness on these matters:

- Offerings and acceptances should follow the contract explicitly.

- Offerings and acceptances on the contract.

- The contract is written, with correspondence, or modern communications.

iii. Treasure or modal is money or asset provided by modal provider for the mudharib to do business with these conditions:

- Capital amount should be clearly mentioned, whether it is in goods, it should be valued in the price of present money (or other types)

- Capital should be in cash not credits

- Capital should be given to the mudharib to do business.

iv. Mudharaba profit is the amount gained from modal's 
advantages. The profits conditions are:

- It should be mentioned by both parties not only one party.

- Profit sharing should be mentioned in percentage of the estimated profit. The profit of the workers and modal owner should be clear. Percentage ratio agreement is the result of negotiation and wrote on the contract.

- Fund provider will bear all loss of the mudharaba, and the manager is not allowed to bear any loss except the ones due to deliberate mistakes, negligent, and agreement violation.

v. The manager business as modal balance is provided by the fund provider. It should follow these conditions:

- Business activities are mudharib exclusive rights without fund provider intervention. Therefore the Shahibul Maal has the right to observe.

- Fund provider is not allowed to limit manager actions, which will obstruct the mudharaba purpose namely profit.

- The manager should not violate sharia law in his action on mudharaba. He should follow the custom of these activities.

c) Mudharaba Financing Legal Provision

Mudharaba financing legal provision at shari'ah bank is mentioned on fatwa DSN-MUI no: 07/DSN-MUI/IV/2000, namely:

- Mudharaba may limit with certain period.

- The contract may not connect to any events in the future which do not necessarily happen.

- In principle there is no compensation in mudharaba due to be mandate nature, except on deliberate mistakes, negligent, or agreement violation.

- If one of the involved parties does not fulfill its obligation or there is conflict of these parties, the settlement is with sharia arbitrage 
institution whether there is no solution after discussion.

\section{Mudharaba Transaction Basic Concept}

Mudharaba is technically a partnership contract of two parties. The first party is modal provider (Shahibul Maal), the second party is the manager (mudharib). The profit shares according to the contract. The loss will bear by the modal owner except it dues to manager negligence. Whether the loss does to the manager fraud it is totally bear by the mudharaba manager. Mudharaba is divided into two types: mudharaba mutlawah, is the mudharaba with modal owner give the manager liberation in managing the investment. Secondly, mudharaba muqayyada, is the mudharaba with modal limit the manager liberation in managing the investment.

The rules of mudharaba are:

1. Modal owner (shahibul maal)

2. Manager/ businessperson (mudharib)

3. Capital (maal)

4. Work or business object (project); and profit and sighat or consent and qabul.

Mudharaba transaction mechanism is carried out by the sharia bank. It is assumed as shahibul maal and customer as mudharib. The operations are:

1. The modal amount is given to the customers as business manager should be in cash. It is in the money format or good which value is mentioned in monetary unit.

2. Mudharaba financing modal management's result is measured with:

a. Business income.

b. Business profit.

3. The profit shares according to agreed contract, every month 
or every agreed period. Bank will bear every loss except due to manager negligence or fraud.

4. Bank has the right to observe the business but not intervened into it.

5. The customer who negligent payment will get administrative sanction.

\section{Banking Application}

Mudharaba is usually applied on financing and funding products. Mudharaba in funding arrangement is applied on saving deposit, is saving with certain purpose, such as hajj saving, qurban saving, general deposit, and others. In addition, special investment is entrusted funding of the customers for certain business such as murabaha or ijara only. The financing is applied on working modal financing, such as trading and service working modal and special investment usually called mudharaba muqayyada is special fund with special distribution with certain rules from the shohibul maal.

Mudharaba is also able to apply with separating or mixing mudharaba fund (Muhammad, 2005). Accordingly, other treasures fund; it is total separation in mudharaba fund including mudharib fund. There is strength and weakness of this technique. The strength is the income and cost are separated and the fund could be correctly calculated. The profit or loss will also be able correctly calculated and allocated. The weakness is the moral hazard and mudharib investment preference. The mudharaba is mixed and combined with other fund sources. This system erase moral hazard and ethics problem mentioned above. However, mudharaba income and cost will be mixed with other costs.

Mudharaba in shariah bank has profit and risk (Syafii, 2005). There are five profits of mudharaba, namely bank will accept profit sharing 
enhancement whether customer business increases. Bank also has no obligation to pay shared profit of the customer's fund on certain time. It will be paid due to the income or bank profit sharing therefore the bank will not experience negative spread. Main fund repayment is in accordance with cash flow or costumer business treasury therefore it will not incriminate the customer. Bank will be more careful and cautious in finding halal, secure, and profitable business due to concrete and real profit is the one to be shared. Furthermore, sharing profit principle in mudharaba or musharaka is different with fixed interest principle. Bank will required financing income with fixed interest from the customer without consideration on profit accepted by the customer, customer's loss, or economic crisis. While, the mudharaba risks are streaming, customer uses the fund in the format as not mentioned on the contract; negligence and deliberate mistakes; and profit concealing by the dishonest customer

\section{Bank Acknowledgement and Measurement as Fund Owner}

Temporary shirkahis distributed by the fund owner. It is acknowledged as mudharaba investment on cash payment or non-cash asset handover to fund manager. Mudharaba investment measurement are carried out with mudharaba investment in cash is measured with the amount at the payment. Mudharaba investment in non-cash asset is measured with noncash asset general value on handover: lower general value than noted value, means loss and higher general value than noted value means deferred profit and amortization at the mudharaba contract period.

Whether the mudharaba investment value decreasing due to damaged, missing, or other factors before the business is starting which not dues to fund manager negligence, it will consider as loss and cut the mudharaba investment balance. Whether part of mudharaba investment is missing after the business is starting and not dues to fund management 
mistake, the loss is calculated on the profit sharing period. Mudharaba business is considered starting since the fund or business modal is accepted by the fund manager. Whether goods non-cash mudharabah investment have value decreasing at the time it is effectively used in mudharabah activities, it will not consider as a loss and cut the investment amount and will be calculated on the profit sharing. Fund manager negligence or mistakes, such as:

1. The agreed conditions is not implemented;

2. There is no general beyond capability condition mentioned on the contract;

3. The decision of the related institution.

4. Whether mudharaba is over before or at the due date contract and has not yet paid by the fund manager, it will consider as due date credit.

Mudharaba according to PSAK 59 is partnership contract of banks as shahibul maal and customer as mudharib with intial agreement of profit sharing. Whether some of mudharaba financing is missing before the business started and it is not the mistake of fund manager (mudharib) the lost is calculated at the profit sharing. While, the financing in noncash modal form in which its value is reduced when it is still in or after effectively used for business, the loss will not directly decrease the total funding but calculated at nks business profit sharing.

However, whether the accident is occuring while the business is operating and based the investigation shows it dues to mudharib mistake the loss will be mudharib's resonsibility. At the end of contract period, the loss will be compensated from the shohibul maals profit sharing.

\section{Some Mudharaba Facilities}

1. Mudharaba Financing Payment (Main Financing) 
Mudharaba financing modal repayment by the mudharib could be done according to the agreement, all at once at the end of the period or gradually in accordance to mudharib's ability. Every mudharaba financing repayment will reduce mudharaba financing credits. Mudharaba financing repayment special with installment needs to attend the reducing of shohibul maal modal proportion dues to its consequence on nisbah reduce as the modal reduce.

Example:

PT. SALAM agrees to provide mudharabah financing for Bank Shari'ah Banget for Rp.1.000.000.000,- in plywood business modal with

\section{At the mudharabab financing provision to the mudharib}

$\begin{array}{ll}\text { Mudharabah Financing Debit } & \text { Rp 1.000.000.000 } \\ \text { Cash/ Account/ Clearing Credit } & \text { Rp 1.000.000.000 }\end{array}$

Calculation principle is justice principle which repaid modal to the shahibul maal is his investment reduce therefore the shohibul maal right on his nisbah is also reducing in accordance with his modal reduce. For example on the 2 nd year before the second modal repayment, PT. SALAM has gained profit of Rp. 100.000.000,- then shabibul maal right is $30 \%$ namely Rp. 30.000.000,- because in the first year PT. SALAM has repaid modal Rp.250.000.000,-. Bank is an institution with prudential principle based on the applicable regulation. It is obligied to record the reduce productive activa difference of $1 \%$ liquidity.

\section{At the Productive activa difference formation (PPAP)}

PPAP expense (obligation format) mudharaba financing debits (1\%) Rp 10.000.000

PPAP accumulation (obligation format) $\mathrm{Kr}$ mudharaba financing credits (1\%) Rp 10.000.000 
2. Mudharabah Profit Loss Sharing acknowledgement

National Sharia Council (DSN) issued fatwa No. 15/DSN-MUI/ IX/2000 on business profit sharing's principle. It said sharia financial institutions are allowed to use revenue sharing principle (income sharing) and profit loss sharing. According to this fatwa due to adavantages for all, the profit loss sharing should be in use is sharing revenue sharing. The prinsciple in use should be agreed upon and the intial contract.

This principle made shohibul maal has never suffered loss unless mudharib business is liquidated with smaller sctiva than his/ her obligation. There is no negative income in this principle due the zero as smallest income (no income). Therefore it is happening the modal repaid is the initial modal (no modal addition.) The profit/ loss sharing principle calculation is carried out with periodical performance. It will calculate income subtracted with expenses which creates profit or loss depend on the bigger one. Mudharib needs to create mudharabah financing management to support this. Whether the modal used by the mudharib does not come from one source, it will need be parting of mudharaba fund using allocation's portion.

It is not easy for a mudharib in fact to create this record periodically due some variables involvement. It is laso not easy for shahibul maal to observe and ensure the allocated expenses on mudharaba funding management. Profit/ loss sharing principle needs honsety of both parties, especially mudharib as funding manager therefore not many sharia bank using this principle.

The basic of mudharaba profit/ loss sharing need to be known in mudharaba principle is profit sharing of shahibul maal and mudharib as agreed upon nisbah, therefore the loss which does not due to Imudharib mistake is the responsibility of shahibul maal responsibility. However the loss dues to mudharib mistake will become mudharib responsibility which will not reduce mudharabah modal of shahibul maal. Mudharib mistake 
or negligence level at least will need these facts: unfulfilled conditions mentioned in the contract; there is no proper force major condition and/ or mentioned on the contract; and the result of shari'ah arbitrate institution or local religious court.

a. Profit Acknowledgement Case

This case uses the illustration of mudharaba contract 1 of Bank Syariah Banget and PT. SALAM with the amount of Rp.1.000.000.000,and nibah 40:60. PT. SALAM manages the mudharabah funding and gains Rp.100.000.000,- as net profits in the first year which immediately shares with Bank Syariah Banget at the second year contract. The sharing portion of each parties are:

Shahibul maal (bank) $\quad=40 \% \times \mathrm{Rp} 100.000 .000 \mathrm{Rp} 40.000 .000$

Mudharib (PT. SALAM) $=60 \% \times \mathrm{Rp} 100.000 .000 \mathrm{Rp} 60.000 .000$

The journal made by Bank Syariah Banget at the profit/ loss sharing are:

Cash Account PT SALAM Debits

$\operatorname{Rp} 40.000 .000$

Profit Sharing Credits

Rp 40.000 .000

b. Loss Acknowledgement Case

1) The loss does not due to PT. SALAM mistake/ negligence

Whether PT. SALAM is suffering loss at the first year Rp. 100.000.000,- and the fact showed it dues to natural disaster which has damaged some of mudharaba activas and it is not possible for the mudharib to avoid it, therefore the journal made by Bank Syariah Banget are:

At the loss reserved mudharaba financing establishment

Mudharaba financing loss allowance expenses Debits

Rp.100.000.000,- 
Mudharaba loss allowance Credits

Rp.100.000.000,-

\section{At the loss reserved mudharaba financing establishment}

Mudharaba bookkeeping allowance debits Rp.100.000.000,-

Mudharaba financing credits

Rp.100.000.000,-

2) The loss dues to PT. SALAM mistake/ negligence

Bank Syariah Banget will not record this in journal beacuse the loss due to to fund manager (mudharib) is the responsible of fund manager without substracting Bank Syariah Banget mudharaba investment. The loss dues to mudharaba financing termination before the contract date dues, therefore the loss is considered as mudharaba finance substraction.

The management loss due to mudharib mistake/ negligence is the responsibility of fund manager (mudharib). Mudharaba financing substraction could be carried out with direct method namely substracting mudharaba financing estimation credits or with indirect method namely establishing mudharaba financing financing termination which is contra account of the financing.

c. Unrealized Profit Loss Sharing Case

Whether PT. SALAM acknowledges the profit of mudharaba financing management of Rp.100.000.000,- and at the agreed date PT. SALAM does not pay the profit loss sharing to Bank Syariah Banget with Rp.40.000.000,-. It will be mentioned in Bank Syariah Banget journal as:

Credits to Mudharib Rp 40.000.000

Mudharabah income credits

Rp 40.000 .000

Mudharaba contract will be terminated dues to agreemenet of both parties, the wish of both parties, or force major suvh as natural disaster or the death of one party. Mudharib should repay the modal to the modal 
owner and whether she/ he does not do it. $\mathrm{He} /$ she is considered violate the contract. The amount of the fund for mudharaba financing credits will change into "mudharib credits expiration date". Both parties have the right to sell and divide the selling result whether the mudharaba contract is dued and there are several non-cash modal in goods with certain values. They are also able to calculate financing credits and profit or loss borne by the mudharaba contract operation. The calculation will be carried out on financing credits, shahibul maal and mudharib rights, the loss and profit of to create new proportion of both parties who renew the contract whether one of the party requires mudharaba contract termination and replaced by other party which is agreed by both parties. The profit or lost proportion shoulb be calculated on every payment correctly whether both parties agree on modal repayment.

Shahibul maal may terminate mudharaba financing at the contract due date on certain situation such as mudharib violates contract or could no longer be trusted. The mudharaba financing credits status will acknowlegde as mudharib due dated credits. For example is government's changing regulation which will terminate PT. SALAM activities before the mudharaba contract date dues therefore Bank Syariah Banget should immediately calculate and require the last financial report from PT. SALAM. Mudharaba financing credits recorded by the bank is Rp.300.000.000,with PT. SALAM reported loss in the period of Rp.50.000.000,-. PT. SALAM is not able to finish the rest of the financing therefore Bank Syariah Banget will record it in the journal as follows:

$\mathrm{Db}$ mudharib credits Rp 250.000.000

$\mathrm{Db}$ mudharabah financing loss allowance Rp 50.000.000 Cr mudharabah financing Rp 300.000.000 


\section{Conclusion}

Mudharaba is a financing and funding contractual form which is able to be given to the customers by sharia bank. There are two mudharaba types in general, namely: mudharaba muthlaqa and mudharaba muqayyada. It needs two inseparable parties shahibul maal and mudharib. The mudharaba system contract is business partnership of two parties. The first party provide all modal, and the other party is the manager. The business profit is divided as the agreement mentioned on the contract. The mudharaba profit on investor is the profit sharing whether the mudharib business profit is increasing. The businessperson however will receive new funding.

The main purpose of mudharaba financing is gaining profit which will be divided as the agreement mentioned on the profit loss contract. Profit is the amount of modal surplus. Profit is the last purpose of mudharaba. The profit's conditions should be fulfilled (Tim Pengembangan Perbankan Syariah Institute Bankir Indonesia: 2002). There are should be two parties and no party gained all without the other. Profit proportion of each party should be known on contract signing as profit percentage. Manager's sharing should state explicitly at the contract signing. However the profit allocation of both parties should be acknowledges at the next period.

Fund provisioner should bear all mudharabah loss, and the manager only bears loss due to his/ her deliberate mistake or negligence. Whether loss dues to business risk and natural disaster the loss bears completely by modal owner, however the losses due to manager's deliberate mistake or negligence will be borne completely by the mudharib. Therefore to minimize the loss dues to mudharib or manager mistake or violation, shabibul maal should create regulations or warning to reduce mudharib action which will create a loss result. 


\section{References}

Al-Kasani, Alauddin, Bada’i. (n.d). As-Syana’i fi Tartib Asy-Syara’i, Juz VI. Bank Indonesia, (2013). Pedoman Akuntansi Perbankan Syariah Indonesia Biro Perbankan Syariah Bank Indonesia, (2001). Islam dan Perbankan Syariah. Jakarta : Karim Business Consulting.

Brian Kettel, (2008). Introduction to Islamic Banking and Finance. London:Printhaus.

Jaih Mubarok. (2013). Hukum Ekonomi Syariah: Akad Mudharabah. Bandung: Fokus Media.

Makhalul Ilmi. (2002). Teori dan Praktek Lembaga Mikro Keuangan Syariah. Yogyakarta: UII Press.

Muhammad. (2005). Kontruksi Mudharabah dalam Bisnis Syariah. Yogyakarta: BPFE.

Muhammad. (2005). Manajemen Bank Syari'ah. Yogyakarta : AMP YKPN. Muhammad. (2008). Manajemen Pembiayaan Mudharabah di Bank Syariah, Jakarta: Raja Grafindo Persada.

Syaf'i Antonio, Muhammad. (2001). Bank Syariah: Dari Teori ke Praktik. Jakarta: Gema Insani Press.

Huda, Nurul dan Heykal, Mohamad. (2010). Lembaga Keuangan Islam Tinjauan Teoritis dan Praktis. Jakarta: Kencana

Syafei, Rachmat. (2001). Fiqih Muamalah. Bandung : Pustaka Setia.

Tim Pengembangan Perbankan Syariah Institute Bankir Indonesia. (2002) Bank Syariah: Konsep, Produk dan Implementasi Operasional Bank Syariah. Jakarta: Djambatan. 


\section{Regulation}

Undang-Undang Republik Indonesia Nomor 21 Tahun 2008 Tentang Perbankan Syariah.

Dewan Standar Akuntansi Keuangan, PSAK No.50 (revisi 2006) tentang Instrumen Keuangan : Penyajian dan pengungkapan dan PSAK No.55 (revisi 2006) tentang pengakuan dan pengukuran instrumen keuangan 2006

Fatwa DSN-MUI nomor: 07/DSN-MUI/IV/2000. 